Tropical Journal of Pharmaceutical Research January 2017; 16 (1): 91-99

ISSN: $1596-5996$ (print); 1596-9827 (electronic)

(C) Pharmacotherapy Group, Faculty of Pharmacy, University of Benin, Benin City, 300001 Nigeria.

All rights reserved.

Available online at http://www.tjpr.org

Original Research Article

http://dx.doi.org/10.4314/tjpr.v16i1.12

\title{
Assessment of oral safety profile of aqueous extract blend of three medicinal spices in Wistar rats
}

\author{
GA Otunola* and AJ Afolayan \\ 5700 , South Africa \\ *For correspondence: Email: gotunola@ufh.ac.za
}

Medicinal Plants and Economic Development (MPED) Research Centre, Department of Botany, University of Fort Hare, Alice

Received: 4 June 2016

Revised accepted: 7 December 2016

\begin{abstract}
Purpose: To evaluate the possible toxicity of a blend of three spices, namely, garlic (Allium sativum), ginger (Zingiber officinale) and cayenne pepper (Capsicum frutescens) in Wistar rats

Methods: For acute toxicity test, five females and five male rats were given a single oral dose of 5000 $\mathrm{mg} / \mathrm{kg}$ body weight of aqueous extract of the spice blend and observed for 14 days. Sub-acute toxicity was assessed by giving male and female rats 200, 500 and $1000 \mathrm{mg} / \mathrm{kg}$ body weight oral doses of the spice blend on a daily basis for 28 days, while controls were administered distilled water. At the end of the experiment, blood and tissues were collected for haematological, biochemical and histological evaluations.

Results: The haematological indices of treated rats did not reveal any significant $(p>0.05)$ differences from those of control except for elevation in lymphocyte count which was significant $(p<0.05)$ in the 500 and $1000 \mathrm{mg} / \mathrm{kg}$ treated male groups. Activities of serum alkaline phosphatise (ALP), gamma glutamyl transpeptidase (GGT), alanine transaminase (ALT), aspartate transaminase (AST) and creatine kinase $(C K)$, as well as concentration of total cholesterol and triglycerides were significantly reduced $(p<0.05)$ following treatment with the extract of the spice blend. Histological examinations of the liver did not reveal any pathological changes attributable to treatment with the spice blend extract.

Conclusions: These findings indicate that oral consumption of a spice blend of garlic, ginger and cayenne pepper in humans may be safe.
\end{abstract}

Keywords: Spice blend, Toxicity, Histology, Marker enzymes, Medicinal, Safety profile

Tropical Journal of Pharmaceutical Research is indexed by Science Citation Index (SciSearch), Scopus, International Pharmaceutical Abstract, Chemical Abstracts, Embase, Index Copernicus, EBSCO, African Index Medicus, JournalSeek, Journal Citation Reports/Science Edition, Directory of Open Access Journals (DOAJ), African Journal Online, Bioline International, Open-J-Gate and Pharmacy Abstracts

\section{INTRODUCTION}

Spices are single or blends of aromatic and pungent herbal substances used as condiments which generally give characteristic taste, flavour, colour and aroma to foods. For ages, spices have been used as seasonings in foods as well as for medicinal purposes. About $80 \%$ of the populations in Africa and Asia still rely on plant extracts, including spices with dietary importance, to treat several health problems such as cancer, diabetes, obesity, hepatic, renal and cardiovascular diseases [1].
Herbal infusions have been recognized as important sources of antioxidants which can be consumed on a daily basis as decoctions. Generally, spices are good sources of antioxidants [2] because of which many spices are now used therapeutically for the maintenance of good health. For example, while some spices are used as carminatives, and for the improvement of circulatory, hypolipidemic, stomachic problems, others are used as stimulants, antispasmodics or for protection against gastrointestinal disturbances. 
Allium sativum L. (garlic), Zingiber officinale Rosc. (ginger) and Capsicum fructescens $\mathrm{L}$. (cayenne pepper) are common spices used in cuisines all over the world. These three spices are available worldwide and are used, often as blends with other spices and medicinal plants for culinary and folkloric medicinal purposes.

Garlic (Alliacae) is effective in preventing heart disease and in boosting immune systems in humans; and the anti-microbial, antihypertensive, anti-cancer, immunomodulatory and hypolipidemic properties of garlic have been reported [3]. Ginger is an herbaceous perennial plant of the family Zingiberacae. Its aromatic and pungent rhizome has been used for centuries throughout the world, especially in Chinese, Japanese and Indian cuisines as spice and medicine. Ginger is well known for its antiinflammatory, anti-cancer, anti-emetic and stomach protective properties $[4,5]$. Cayenne pepper belongs to the Solanaecae family and is a source of important vitamins such as $A, C$ and E. Its constituents include polyphenols, capsaicinoids and carotenoids. Traditionally, cayenne is used as remedy for rheumatic and arthritic pains, in the treatment of hyperglycaemia and hypercholesterolemia [6,7]. The species has also been reported to enhance lymphocyte proliferation and serum immunoglobulin levels as well as to correct erectile dysfunction.

Although most of the spices used for dietary, culinary and medicinal purposes are relatively safe and non-toxic to consumers, however, investigation of medicinal plants and their ability to produce toxic and adverse consequences is of current research focus $[8,9]$. It is therefore, necessary to evaluate and scientifically examine the possible acute and sub-acute toxicities of spices especially those that are consumed in large quantities.

The beneficial health effects and safety of each of garlic, ginger and cayenne pepper have been extensively studied $[4,6,10,11,15,16]$. However, despite long record of usage for various purposes, there is a dearth of information on the toxicity/safety of their associated use as a blend in the literature. Therefore, this study was undertaken to determine the possible oral toxicity of the aqueous extract of this spice blend in rats.

\section{EXPERIMENTAL}

\section{Collection and preparation of the spice blend}

The fresh spices were purchased from the vegetable market in Alice, Eastern Cape, South Africa. The individual spices were cleaned, sliced, dried at $60{ }^{\circ} \mathrm{C}$ for $72 \mathrm{~h}$ and then pulverised. Equal amount of each spice was weighed $(1: 1: 1, \mathrm{w} / \mathrm{w} / \mathrm{w})$ and mixed thoroughly to give the spice blend. The aqueous extract of the spice blend was obtained by extracting $50 \mathrm{~g}$ of the spice in $1000 \mathrm{~mL}$ of distilled water at $100{ }^{\circ} \mathrm{C}$ for $60 \mathrm{~min}$. The filtrate was freeze-dried and stored $4{ }^{\circ} \mathrm{C}$.

\section{Experimental animals}

Adult male and female (nulliparous) Wistar rats $(175$ - $195 \mathrm{~g})$ were obtained from the Animal Unit, of the University of Fort Hare, South Africa. The rats were divided into groups of control and spice treated, with 5 male and 5 female rats in each group. The rats were kept under standard laboratory conditions (12 h light and dark cycle; $24 \pm 2{ }^{\circ} \mathrm{C}$ ). The animals were fed with standard rat pellet diet and water ad libitum. The study was carried out and the animals were handled according to the guidelines of the National Research Council Guide for the Care and Use of Laboratory Animals [12]. The study was approved by the University of Fort Hare Animal Use Research Ethics Committee (AREC: AFO011). approved by the Animal Use Ethics Committee, University of Fort Hare, Alice, South Africa.

\section{Acute toxicity}

Acute toxicity of the spice mixture was evaluated following the Organization for Economic Cooperation and Development guidelines 420. Limit dose of $5000 \mathrm{mg} / \mathrm{kg}$ body weight was used [13] $[18,19]$. The rats were administered a single oral dose (5000 mg/kg body weight) of the spice extract and observed for body weight, signs of toxicity and mortality during 14 days. The rats were fasted for $16-18 \mathrm{~h}$ and then sacrificed. The liver, kidney, heart, lung and pancreas were removed, weighed and observed for any histopathological defects.

\section{Sub-acute toxicity}

Sub-acute toxicity was conducted according to the OECD [14,20,21] guidelines. The animals were distributed into four groups made up of 10 rats (5 males and 5 females) each. Three of the groups [male: nulliparous female $=1: 1$; (rats of opposite sex were placed in different cages)] were given doses (200, 500 and $1000 \mathrm{mg} / \mathrm{kg}$ body weight) of the spice extract by oral gavage. The $4^{\text {th }}$ group (control) received distilled water for 28 days. The animals were weighed on the first day of the experiment and then every week for 28 days. At the end of the experiment ( $29^{\text {th }}$ day) blood samples were collected through the 
common carotid artery of fasted animals under anaesthesia (3\% pentobarbital sodium; dose: 50 $\mathrm{mg} / \mathrm{kg}$ ). Parts of the liver were fixed in $10 \%$ formalin for histopathological examination.

\section{Determination of haematological and biochemical parameters}

An automated haematology analyzer (Beckman Coulter, Inc, USA) was used to determine blood parameters; while a chemistry analyser (Abaxis Inc, Union City, CA, USA.) was used for the biochemical indices. Haematological parameters evaluated include haemoglobin, red blood cell (RBC), white blood cell (WBC) and platelet (PLT) counts. Other parameters include haematocrit, mean corpuscular volume (MCV), mean corpuscular haemoglobin concentration (MCHC) and white blood cell differential count.

Biochemical indices determined were serum electrolytes, total protein, total cholesterol and triglycerides. Also estimated were serum marker enzymes for liver, kidney and heart functions including alkaline phosphatase (ALP), gamma glutamyl transpeptidase (GGT), creatine kinase (CK), alanine and aspartate amino transaminases (ALT, AST).

\section{Histopathological analysis}

Thin sections of the liver already fixed in $10 \%$ formalin were prepared, embedded in paraffin wax, stained with hematoxylin/eosin and examined under the light microscope for histopathological anomalies.

\section{Statistical analysis}

Data are expressed as mean \pm standard deviation ( $S D, n=5)$. A single-factor parametric one-way analysis of variance, followed by Duncan's Multiple Range Test was used to determine significant differences among treatment means. Data were considered significant at $p<0.05$. All statistical analyses were performed using the Minitab Student Version 12 for Windows Software (Minitab, Inc. State College, Pennsylvania) Minitab version 12.

\section{RESULTS}

\section{Acute toxicity}

The limit test results revealed that a single oral dose of aqueous extract of the spice mixture (garlic, ginger and cayenne pepper), did not cause mortality of the rats within $72 \mathrm{~h}$ and during the $14 \mathrm{~d}$ observatory period. No obvious adverse clinical or behavioural changes attributable to toxicity of the extract were observed. Furthermore, there was no anomaly in food and water intake (data not shown) of the rats. In addition, body weight gain was not affected by the spice extract neither was there any evident sex-related differences.

\section{Sub-acute toxicity}

Effect of the spice blend extract on body and relative organ weights of rats revealed that doses of 200,500 and $1000 \mathrm{mg} / \mathrm{kg}$ body weight for 28 days produced no mortality in either sex. There were no clinical signs of diarrhoea, scabbing, loss of appetite, pilo-erection, lacrimation, convulsion, salivation, voicification and prostration during the period of exposure to the spice extract. In addition, body and organ weights were not significantly different among treated and control animals (Figure 1).

\section{Effect of sub-acute administration of spice blend extract on blood and biochemical indices}

Administration of extract of the spice blend for 28 d revealed no significant change in the blood parameters of treated rats except for an increase in lymphocyte count, as well as a decrease in the monocyte count of rats given the 500 and 1000 $\mathrm{mg} / \mathrm{kg}$ doses respectively (Figure 2). Table 1 shows the effect of the spice blend extract on lipid and electrolyte profiles of the animals.

Effect of the spice extracts on hepatic, renal and cardiac enzymes are shown in Figure 3 . Significant $(p<0.05)$ dose-dependent reduction in the activities of ALP, ALT and CK was observed in all the rats given the spice blend extract. None statistically significant decrease in the activities of aspartate amino transaminase and gamma glutamyl transpeptidase were also recorded for the treated animals.

\section{Effect of sub-acute administration of aqueous extract of spice blend on histology of rat organs}

Histopathological examination of the liver did not reveal any spice blend induced changes. Figure 4 reveals that no lesions, necrosis or pathological changes were present in the liver of the spice blend treated rats. No lesions, necrosis or pathological changes of the various organs were observed in all the treated groups. 

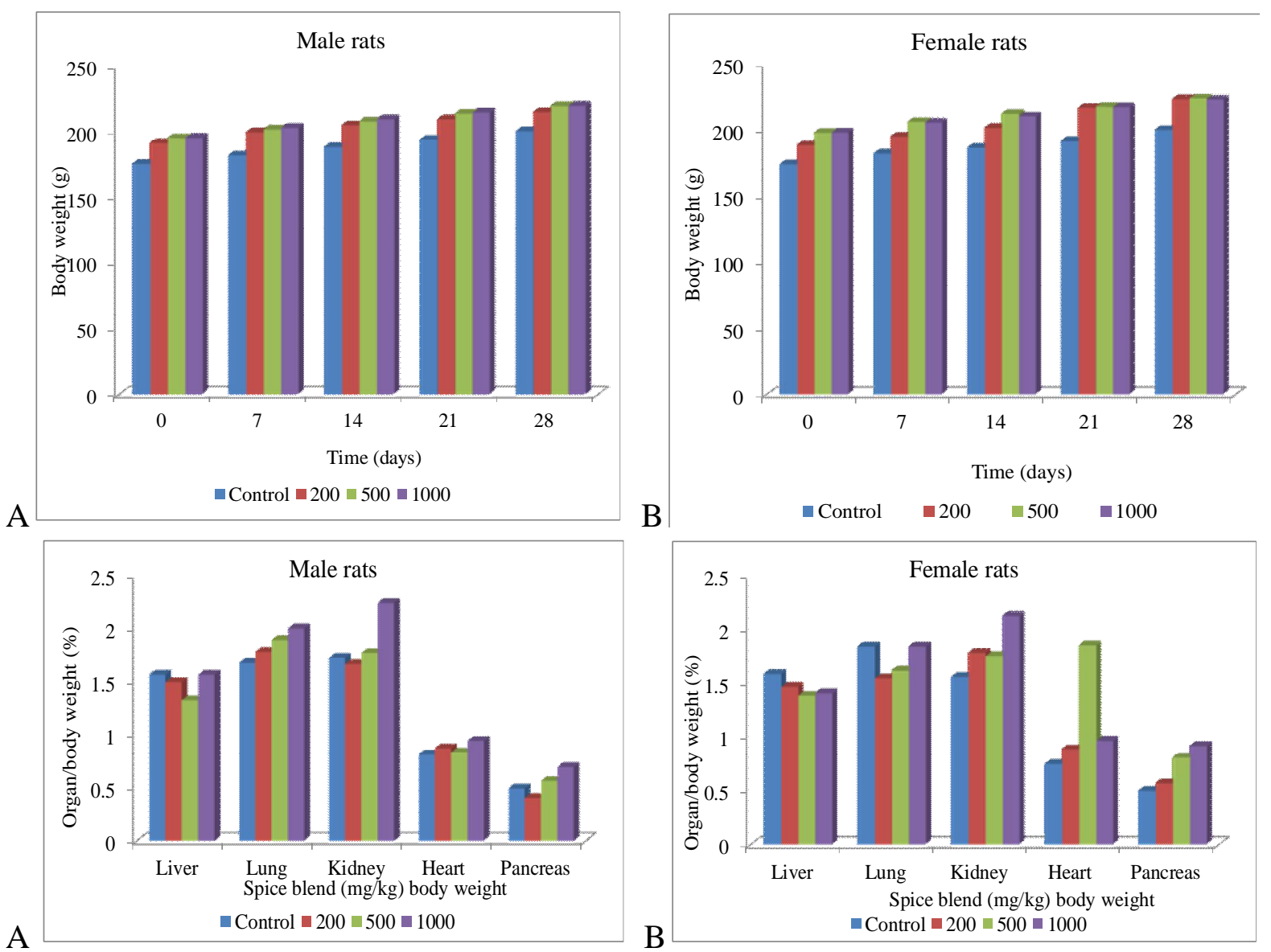

Figure 1: Body weights of A- male, B- female rats and relative organ to body weights $C, D$ following 28-days sub-acute oral administration with different doses of spice blend. Values are means $\pm S D(n=5)$. Spice blend administered at 200, 500, $1000 \mathrm{mg} / \mathrm{kg}$ body weight doses respectively

Serum total cholesterol, triglycerides, total protein, creatinine and urea concentrations were significantly $(p<0.05)$ reduced in the treated rats compared to control. In addition, the magnesium and chloride ion concentrations of the treated rats (both male and females), were also significantly different $(p<0.05)$ compared to the control.

\section{DISCUSSION}

In acute toxicity study, rats administered extract of the spice blend at the limit dose of $5000 \mathrm{mg} / \mathrm{kg}$ did not show any signs of toxicity such as excessive loss in body weight, increased organ weight or general physical and physiological misbehaviour. This is an indication that the noobserved-adverse-effect-level (NOAEL) of the extract is greater than the limit dose and that the spice blend at a dose of $5000 \mathrm{mg} / \mathrm{kg}$ weight had no toxic effect on rats.

Although spices and spice blends have been used traditionally for their culinary and medicinal properties, there are little or no studies reporting their safety on repeated uses. In this study, we report that sub-chronic administration of the spice blend extract at 200, 500 and 1000 $\mathrm{mg} / \mathrm{kg} /$ day for 28 days, was not toxic.

Body and organ weights of experimental animals are important tools used in toxicity evaluation of drugs and plant extracts. According to Teo et al [15], loss in body and relative organ weights are indicative of toxicity.

In this study, we observed no significant differences in body weights of rats following repeated oral administration of the spice for 28 days at different doses. All the experimental animals exhibited increase in body weight commensurate with feed intake and no statistical differences in the organs investigated. These observations (increase in body weight and lack of any effect on organ weight and mortality) could be attributed to the nutrient content of the feed, as well as antioxidant constituents such as flavonoids, phenols and alkaloids present in the spice blend [16]. Since no reduction in body weight and organs of the treated rats was observed at all the doses, this suggests that the spice blend is not toxic. 

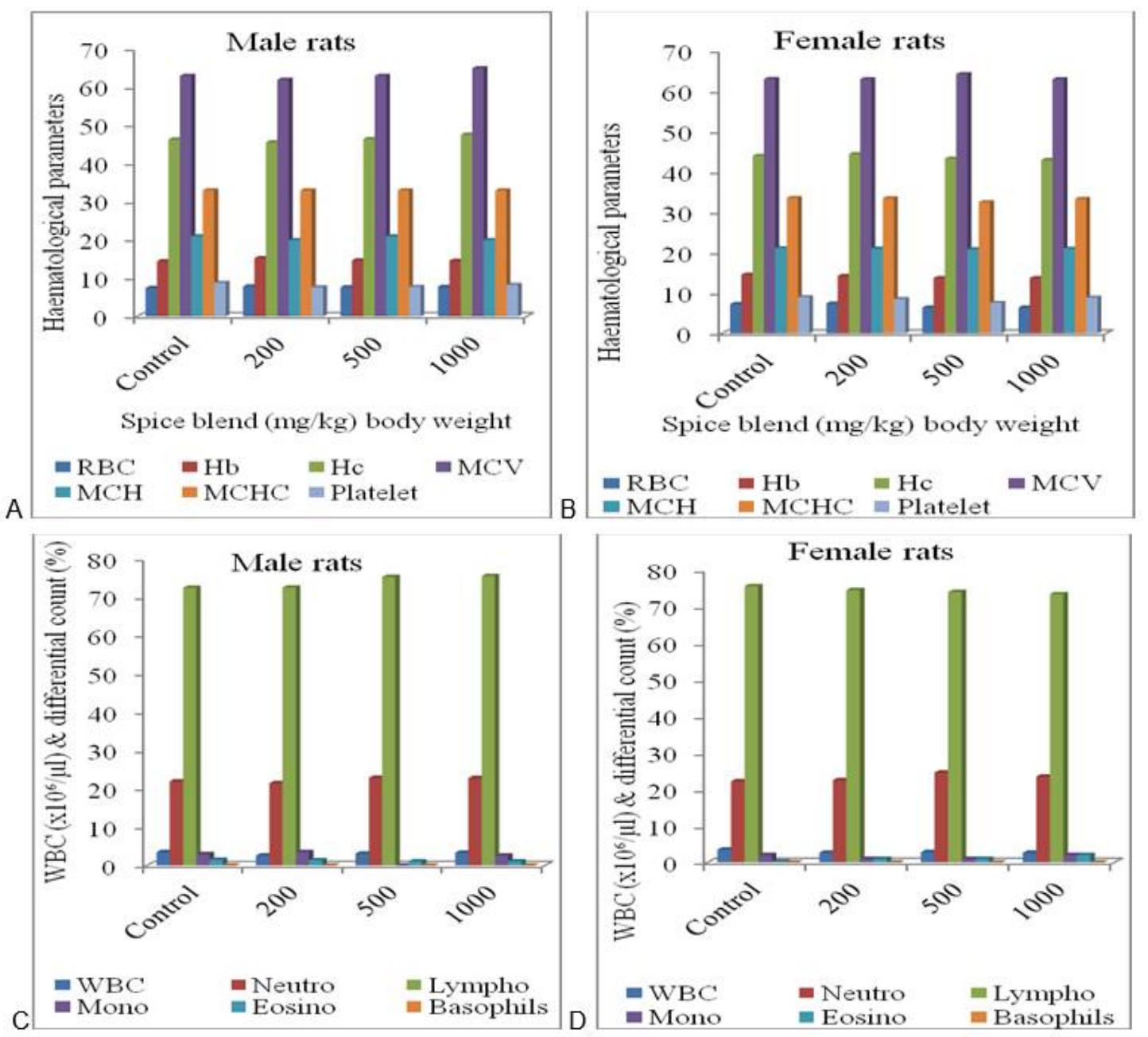

Figure 2: Haematological indices of male and female rats following 28-days sub-acute oral administration at different doses of spice mixture. Values are means $\pm S D(n=5), \quad R B C\left(\times 10^{6} / \mu l\right)$-red blood cell count, Hbhaemoglobin ( $\mathrm{g} / \mathrm{dl})$, Hc-haematocrit (\%), MCV-mean corpurscular volume (fl), MCHC-mean corpurscular haemoglobin concentration ( $\mathrm{g} / \mathrm{dl})$, Platelet $\left(\times 10^{5} / \mu \mathrm{l}\right), W B C\left(\times 10^{6} / \mu \mathrm{l}\right)$-white blood cell count, Neutro (\%)-neutrohpils, Lympho (\%)-lymphocytes, Eosino (\%)-eosinophils

Another important index of toxicity is the haematopoietic system, which has been reported to be highly indicative especially when data from animal studies are extrapolated for humans [17]. Treatment with extract of the spice blend did not produce any deleterious effect on haematological parameters, suggesting that the haematological system was not affected by the spice extract. The concentration dependent increase in lymphocytes is an indication that the spice extract contains bioactive compounds that can boost the immune system, while reduced monocytes suggest the absence of infection. These are good indicators of the absence of inflammation and toxicity; and support the reported lymphocyte proliferation and immunomodulatory properties of the spices $[5,18,19,25,26]$. Moreover, all the changes observed were within normal ranges.
The major site for metabolism of cholesterol, sugar, nutrients and drugs is the liver. Significantly lower values of cholesterol, triglycerides and glucose in the treated rats corroborates earlier report on the hypolipidaemic property of aqueous extract of the mixture of garlic, ginger and pepper in rats [20]. This implies that the mixture possess both hypolipidaemic and hypoglycaemic properties.

Evaluation of liver and kidney functions are very important in toxicity assessment of plant extracts because both organs are necessary for the survival and wellbeing of an organism. Electrolyte functions are often considered when assessing kidney function. Increase or decrease in electrolytes such as sodium, potassium, chloride and magnesium ions could indicate renal injury [21]. Kidney function assessed using 
Table 1: Effects of aqueous extract of spice mixture (garlic, ginger and cayenne pepper) on blood biochemistry of Wistar rats following a 28-day sub-acute treatment

\begin{tabular}{|c|c|c|c|c|}
\hline Parameter & Control (mg/kg) & $200(\mathrm{mg} / \mathrm{kg})$ & $500(\mathrm{mg} / \mathrm{kg})$ & $1000(\mathrm{mg} / \mathrm{kg})$ \\
\hline \multicolumn{5}{|l|}{ Male rats } \\
\hline Cholesterol (mmol/l) & $2.63 \pm 0.11^{a}$ & $1.04 \pm 0.22^{b}$ & $1.14 \pm 0.08^{\mathrm{b}}$ & $1.06 \pm 0.05^{b}$ \\
\hline Triglycerides $(\mathrm{mmol} / \mathrm{l})$ & $0.53 \pm 0.01^{a}$ & $0.38 \pm 0.05^{\mathrm{D}}$ & $0.50 \pm 0.16^{\mathrm{a}}$ & $0.36 \pm 0.03^{\mathrm{b}}$ \\
\hline Glucose (mmol/l) & $3.74 \pm 1.23^{\mathrm{a}}$ & $3.26 \pm 0.76^{\mathrm{a}}$ & $3.72 \pm 1.44^{\mathrm{a}}$ & $3.28 \pm 0.92^{\mathrm{a}}$ \\
\hline Total protein (mg/dl) & $63.00 \pm 1.41^{\mathrm{a}}$ & $63.40 \pm 2.00^{\mathrm{a}}$ & $57.40 \pm 4.09^{\mathrm{b}}$ & $62.00 \pm 1.23^{\mathrm{a}}$ \\
\hline Albumin (mg/dl) & $34.20 \pm 1.07^{\mathrm{a}}$ & $35.00 \pm 0.00^{\mathrm{a}}$ & $33.80 \pm 0.84^{\mathrm{ab}}$ & $35.00 \pm 1.00^{\mathrm{a}}$ \\
\hline Creatinine $(\mu \mathrm{mol} / \mathrm{l})$ & $23.60 \pm 3.13^{\mathrm{a}}$ & $22.20 \pm 3.29^{\mathrm{b}}$ & $22.00 \pm 6.78^{\mathrm{b}}$ & $22.40 \pm 1.09^{b}$ \\
\hline Urea (mmol/l) & $6.40 \pm 2.24^{\mathrm{a}}$ & $6.80 \pm 0.41^{\mathrm{a}}$ & $5.50 \pm 1.34^{\mathrm{b}}$ & $4.26 \pm 0.84^{\mathrm{bc}}$ \\
\hline Sodium (mmol/l) & $139.20 \pm 2.17^{\mathrm{a}}$ & $141.00 \pm 1.87^{\mathrm{a}}$ & $141.40 \pm 2.19^{\mathrm{a}}$ & $140.20 \pm 0.84^{\mathrm{a}}$ \\
\hline Chloride (mmol/l) & $103.80 \pm 1.30^{\mathrm{a}}$ & $103.20 \pm 1.79^{a}$ & $101.40 \pm 0.89^{\mathrm{b}}$ & $104.00 \pm 0.00^{\mathrm{ac}}$ \\
\hline Potassium (mmol/l) & $6.00 \pm 0.58^{\mathrm{a}}$ & $5.76 \pm 0.27^{\mathrm{b}}$ & $6.98 \pm 1.22^{\mathrm{a}}$ & $5.54 \pm 0.25^{b}$ \\
\hline Magnesium (mmol/l) & $0.79 \pm 0.53^{\mathrm{a}}$ & $1.10 \pm 0.04^{b}$ & $1.19 \pm 0.11^{\mathrm{b}}$ & $1.15 \pm 0.07^{\mathrm{b}}$ \\
\hline Calcium (mmol/l) & $2.40 \pm 0.17^{\mathrm{a}}$ & $2.45 \pm 0.06^{\mathrm{a}}$ & $2.55 \pm 0.08^{\mathrm{a}}$ & $2.45 \pm 0.05^{\mathrm{a}}$ \\
\hline \multicolumn{5}{|l|}{ Female rats } \\
\hline Cholesterol (mmol/l) & $2.74 \pm 0.05^{\mathrm{a}}$ & $2.77 \pm 0.33^{\mathrm{a}}$ & $2.40 \pm 0.18^{\mathrm{D}}$ & $2.40 \pm 0.54^{\mathrm{D}}$ \\
\hline Triglycerides (mmol/l) & $0.52 \pm 0.00^{\mathrm{a}}$ & $0.55 \pm 0.13^{\mathrm{a}}$ & $0.53 \pm 0.01^{\mathrm{a}}$ & $0.51 \pm 0.23^{\mathrm{a}}$ \\
\hline Glucose $(\mathrm{mmol} / \mathrm{l})$ & $3.74 \pm 1.23^{\mathrm{a}}$ & $3.26 \pm 0.76^{\mathrm{ab}}$ & $3.72 \pm 1.44^{\mathrm{a}}$ & $3.28 \pm 0.92^{\mathrm{ab}}$ \\
\hline Total protein $(\mathrm{mg} / \mathrm{dl})$ & $64.40 \pm 0.55^{\mathrm{a}}$ & $62.40 \pm 1.71^{\mathrm{b}}$ & $61.80 \pm 2.05^{\mathrm{b}}$ & $61.40 \pm 2.07^{\mathrm{b}}$ \\
\hline Albumin (mg/dl) & $33.60 \pm 0.55^{\mathrm{a}}$ & $32.40 \pm 0.78^{\mathrm{a}}$ & $31.20 \pm 1.09^{\mathrm{ab}}$ & $30.60 \pm 0.55^{\mathrm{ab}}$ \\
\hline Creatinine $(\mu \mathrm{mol} / \mathrm{l})$ & $20.40 \pm 3.72^{\mathrm{a}}$ & $20.78 \pm 1.98^{\mathrm{a}}$ & $20.35 \pm 1.09^{a}$ & $20.20 \pm 2.78^{\mathrm{a}}$ \\
\hline Urea $(\mathrm{mmol} / \mathrm{l})$ & $6.44 \pm 0.54^{\mathrm{a}}$ & $6.40 \pm 0.51^{\mathrm{a}}$ & $5.49 \pm 0.33^{\mathrm{b}}$ & $5.86 \pm 0.56^{\mathrm{b}}$ \\
\hline Sodium (mmol/l) & $136.20 \pm 1.09^{a}$ & $137.40 \pm 0.81^{\mathrm{ab}}$ & $138.60 \pm 0.55^{\mathrm{ab}}$ & $137.00 \pm 0.71^{\mathrm{ab}}$ \\
\hline Chloride $(\mathrm{mmol} / \mathrm{l})$ & $102.60 \pm 0.55^{a}$ & $103.40 \pm 1.67^{\mathrm{ab}}$ & $103.60 \pm 1.21^{\mathrm{ab}}$ & $103.40 \pm 1.14^{\mathrm{ab}}$ \\
\hline Potassium (mmol/l) & $6.24 \pm 0.43^{a}$ & $5.70 \pm 1.21^{\mathrm{b}}$ & $5.36 \pm 0.08^{\mathrm{b}}$ & $5.04 \pm 0.71^{\mathrm{b}}$ \\
\hline Magnesium $(\mathrm{mmol} / \mathrm{l})$ & $1.13 \pm 0.08^{\mathrm{a}}$ & $1.26 \pm 0.54^{\mathrm{a}}$ & $1.08 \pm 0.07^{\mathrm{a}}$ & $1.13 \pm 0.11^{\mathrm{a}}$ \\
\hline Calcium $(\mathrm{mmol} / \mathrm{l})$ & $2.52 \pm 0.19^{a}$ & $2.59 \pm 0.12^{\mathrm{a}}$ & $2.56 \pm 0.06^{\mathrm{a}}$ & $2.62 \pm 0.01^{\mathrm{a}}$ \\
\hline
\end{tabular}

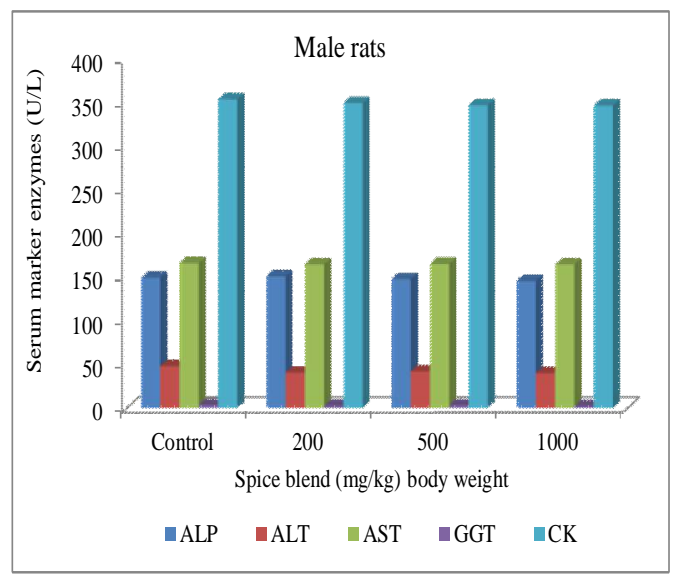

A

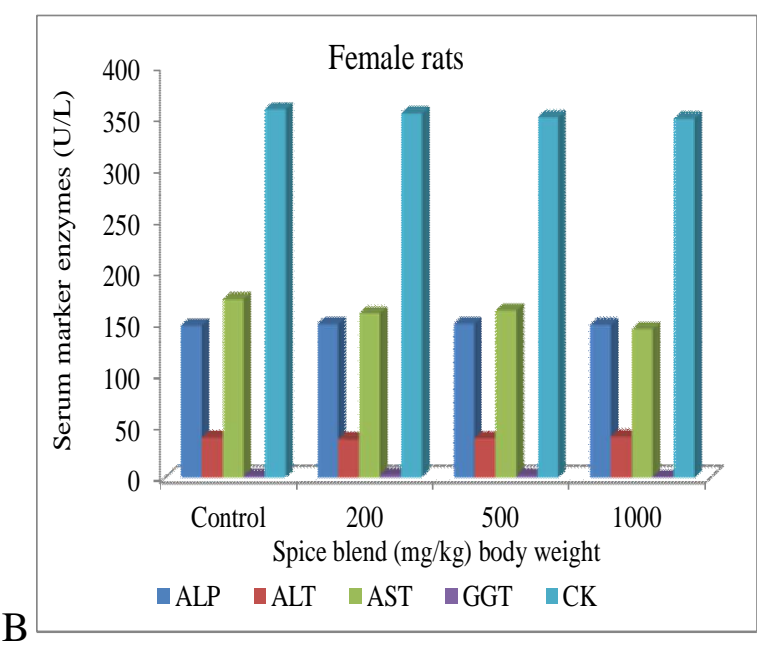

Figure 3: Serum marker enzymes of A-male and B-female rats following 28-days sub-acute oral administration with different doses of spice mixture. Values are means $\pm S D$ ( $n=5 /$ sex/dose), Spice blend administered at 200, $500,1000 \mathrm{mg} / \mathrm{kg}$ body weight doses, respectively

serum creatinine, urea and electrolyte concentrations in this study indicates that these parameters were not significantly affected by treatment with the spice extract and therefore, do not alter kidney function at all the doses investigated.

Measurement of serum enzymes are often used as indicators and type of damage to any organ or tissue. Several enzymes found in the serum are present because of leakage from damaged tissues due to alteration in membrane permeability. The transaminases (ALT and AST), ALP, GGT and CK are well known predictors of toxicity [22]. The modest dose-dependent reduction of these marker enzymes observed in this study, suggests inhibition or inactivation of enzyme activities in situ by the bioactive com- 

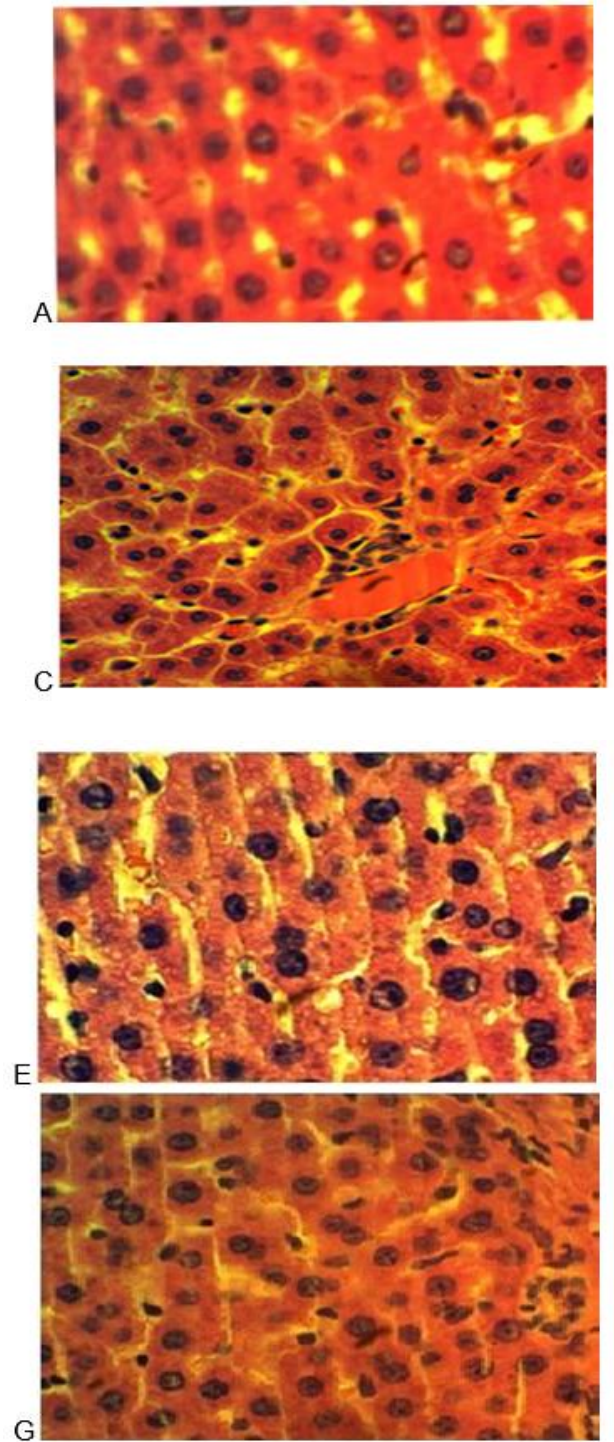
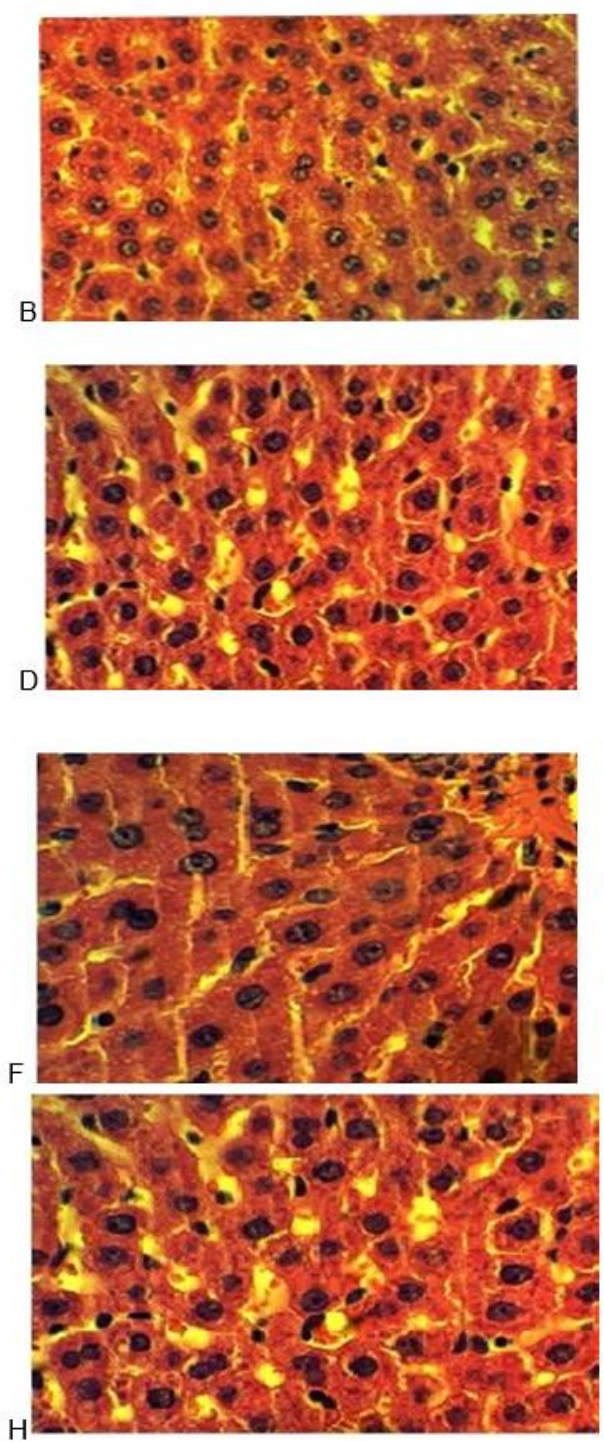

Figure 4: Micrographs showing liver architecture of A,B- control; C,D-1000 mg/kg; E,F-500 mg/kg; and G,H-200 $\mathrm{mg} / \mathrm{kg}$ body weight of male and female rats administered the spice blend extract

pounds present in the spices. Sulphur containing amino acids such as allicin present in garlic have been reported to decrease the activities of serum enzymes like ALP, AST and ALT [3,11]. In this study, we observed no negative indices of hepatic, nephrotic or cardiac functions, suggesting that the sub-chronic administration of the spice blend did not compromise these organs.

Histopathological assessment of tissues and organs are often used to provide supportive evidence for haematological and biochemical observations in toxicity studies. In this study, the absence of any morphological alterations, abnormalities, specific changes or lesions in the liver architecture of the treated rats compared with the control, supported the biochemical results that repeated intake of the spice blend orally at the given doses had no toxic effect on the liver. Thus, these results indicated the healthy status of the liver in the treated rats.

\section{CONCLUSION}

To the best of our knowledge, this is the first report on the acute and sub-acute oral toxicity profile of a spice blend of garlic, ginger and cayenne pepper. The findings could be useful in future clinical studies of the therapeutic properties of this spice blend. The results indicated that oral consumption of aqueous extract of the spice blend may be safe at the doses investigated.

\section{DECLARATIONS}

\section{Acknowledgement}

Trop J Pharm Res, January 2017; 16(1): 97 
This research was supported by National Research Foundation (NRF) and Medical Research Council (MRC) both of South Africa.

\section{Conflict of Interest}

No conflict of interest associated with this work.

\section{Contribution of Authors}

The authors declare that this work was done by the authors named in this article and all liabilities pertaining to claims relating to the content of this article will be borne by them.

\section{Open Access}

This is an Open Access article that uses a funding model which does not charge readers or their institutions for access and distributed under the terms of the Creative Commons Attribution License (http://creativecommons.org/licenses/by 14.0) and the Budapest Open Access Initiative (http://www.budapestopenaccessinitiative.org/rea d), which permit unrestricted use, distribution, and reproduction in any medium, provided the original work is properly credited.

\section{REFERENCES}

1. Mishra BB, Tiwari VK. Natural products: an evolving role in future drug discovery. Eur. J Med Chem 2011; 46: 4769-4807. Europ J Medicin Chem 2011; 46: 47694807.

2. Ranjbar SH, Larijani B, Abdollahi M. Recent update on animal and human evidences of promising antidiabetic medicinal plants: A mini-review of targeting new drugs. Asian J Animal Vet Adv 2011; 6:1271-1275.

3. Mikaili P, Maadirad S, Moloudizargari M, Aghajanshakeri $S$, Sarahroodi S. Therapeutic uses and pharmacological properties of garlic, shallot, and their biologically active compounds. Iran J Basic Med Sci 2013; 16(10): 10311048

4. Haniadka R, Rajeev AG, Palatty PL, Arora R, Baliga MS. Zingiber officinale (Ginger) as an anti-emetic in cancer chemotherapy: A Review. J Altern Complimen Med 2012; 18:440-444.

5. Yiming Li, Tran VH, Duke CC, Roufogalis BD. Preventive and Protective Properties of Zingiber officinale (Ginger) in diabetes mellitus, diabetic complications, and associated lipid and other metabolic disorders: A Brief Review. Evid-based Complemen Altern Med 2012; doi:10.1155/2012/516870.

6. Ahuja KD, Robertson IK, Geraghty DP, Ball MJ. Effects of chili consumption on postprandial glucose, insulin, and energy metabolism. Am J Clin Nutr 2006; 84(1): 63-69.

7. Dominguez-Canedo IL, Beristain-Guevara Cl. Microencapsulation of Habanero chilli (Capsicum chinense) oleoresin in $\beta$-ciclodextrin and antioxidant activity during storage. European Drying ConferenceEuroDrying 2011. Palma. Balearic Island, Spain, 26-28 October 2011.

8. Cao Y, Colegate SM, Edgar JA. Safety assessment of food and herbal products containing hepatotoxic pyrrolizidine alkaloids: Inter laboratory consistency and the importance of $\mathrm{N}$-oxide determination. Phytochem Anal 2008; 19:526-533.

9. Obidike I, Salawu O. New insights into toxicity and drug testing. In: Screening of herbal medicines for potential toxicities. INTECH 2013; pp 64-88 http://dx.doi.org/ 10.5772/54493.

10. Rong X, Peng G, Suzuki T, Yang Q, Yamahara J, Li Y. A 35-day gavage safety assessment of ginger in rats. Regulat Toxicol Pharmacol 2009: 54 (2):118-123.

11. Hamlaoui-Gasmi S, Limam N, Mokni M, Limam F, Aouani E, Amri M, Marzouki L. Garlic-mode treatment effects on rat brain redox status. J Med Plant Res 2011; 5(20):5094-5098.

12. National Research Council: Guide for the Care and Use of Laboratory Animals, Committee on Care and Use of Laboratory Animals. Institute of Laboratory Animal Resources DHHS (NIH Publication No. 1985:85-93).

13. Organization of Economic Cooperation and Development (OECD). Acute Oral toxicity: Acute Oral Toxicity Methods. Guideline 423 2001; 1-13.

14. Organization for Economic Cooperation and Development (OECD). OECD Guidelines for the testing of chemicals- Repeated dose 28-day oral toxicity in rodents. No. 407 2008; 1-14.

15. Teo S, Stirling D, Thomas S, Hoberman A, Kiorpes A, Khetani V. 2002. A 90-day oral gavage toxicity study of $D$-methylphenidate and $D, \quad L$-methylphenidate IN Sprague-Dawley rats. Toxicol 2002; 179: 183-196.

16. Ye BG, Feng $Y$, Wang $S$. Scientific evaluation of the acute toxicity and 13-week sub-chronic toxicity of Rheum emodi rhizome extracts in Sprague Dawley rats. Food Chem Toxicol 2014; 66:278-285.

17. Diallo A, Eklu-Gadegkeku K, Agbonon A, Aklikokou K, Creppy E, Gbeassor M. Acute and sub-chronic (28-day) oral toxicity studies of hydroalcohol leaf extract of Ageratum conyzoides L (Asteraceae). Trop J Pharm Res 2010; 9(5): 463-467.

18. Yu R, Park JW, Kurata T, Erickson KL. Modulation of select immune responses by dietary capsaicin. Intern $J$ Vitamin Nutr Res 1998; 68:114-119.

19. Jafarzadeh A, Azizi SV, Nemati M, Khoramdel-Azad $H$, Shamsizadeh A, Ayoobi F, Taghipour Z, Hassan ZM. Ginger extract reduces the expression of IL-17 and IL23 in the sera and central nervous system of EAE mice. Iran J Immunol 2015; 12(4):288-301.

20. Otunola GA, Oloyede HOB, Oladiji AT, Afolayan AJ. Hypolipidemic effect of aqueous extracts of selected spices and their mixture on diet-induced hypercholesterolemia in Wistar rats. Can J Pure Appl Sci 2012; 6(3): 2063-2071. 
21. Oh MS. Evaluation of renal function, water, electrolytes and acid-base balance. In: McPherson RA, Pincus MR, eds. Henry's Clinical Diagnosis and Management by Laboratory Methods. 22nd ed. Philadelphia, PA: Elsevier Saunders; 2011; chap 14.
22. Rahman MF, Saddiqui MK, Jamil K. Effects of vepacide (Azadirachta indica) on aspartate and alanine aminotranferase profiles in sub chronic study with rats. $J$ Human Exper Toxicol 2001; 20: 243-249. 